\title{
IN VIVO ANTITRYPANOSOMAL EFFECTS OF SOME ETHNOMEDICINAL PLANTS FROM NUPELAND OF NORTH CENTRAL NIGERIA
}

\author{
Abdullahi Mann ${ }^{1, *}$, Oluwaseyi R. Ifarajimi ${ }^{1}$, Abdulfatai T. Adewoye ${ }^{1}$, Chidiebere Ukam ${ }^{1}$, Ekpenyong \\ E. Udeme ${ }^{1}$, Isaac I. Okorie ${ }^{2}$, Mohammed S. Sakpe ${ }^{2}$, Dauda R. Ibrahim ${ }^{2}$, Yusuf A. Yahaya ${ }^{1}$ Adamu Y. \\ Kabir $^{2}$ and Emmanuel O. Ogbadoyi ${ }^{2}$
}

${ }^{1}$ Department of Science Laboratory Technology, Federal Polytechnic Bida, P. M. B. 55, Bida, Niger State, Nigeria, ${ }^{2}$ Department of Biochemistry, Federal University of Technology Minna, P. M. B. 65, Minna Niger State Nigeria

*E-mail: abdumann@yahoo.com, eogbadoyi@yahoo.com

\begin{abstract}
Four medicinal plants Acacia nilotica, Bombax buonopozense, Terminalia avicennioides and Zanthoxylum zanthoxyloides traditionally used for treatment of sleeping sickness in Nupeland were investigated for in vivo antitrypanosomal activity. Methanol extracts of different parts of each plant (stem barks and fruits) were obtained and evaluated for their in vivo antitrypanosomal activities against Trypanosoma brucei brucei. Phytochemical screening of the methanol extracts of each plant were performed by standard procedures. Methanol extracts of A. nilotica (stem bark), B. buonopozense (stem bark), T. avicennioides (round fruit) and Z. zanthoxyloides (stem bark) were effective on trypanosomes. The extracts of A. nilotica and B. buonopozense exhibited antitrypanosomal effects at 200 and $300 \mathrm{mg} / \mathrm{kg}$ body weight respectively. Doses were able to clear the parasites from circulation within 6 and 7 days of treatment respectively with prolonging survival period of up to 30 days. While the extracts of T. avicennioides and Z. zanthoxyloides showed trypanostatic effects and could not clear the parasites completely. The methanol extracts of these plants contain metabolites that are associated with antitrypanosomal effects; therefore, these medicinal plants may be sources of new compounds that may be active against $T$. b. brucei. This study has also justified the claim that some medicinal plants of Nupeland possess antitrypanosomal activity and could be useful in the management of trypanosomiasis.
\end{abstract}

Key words: Antitrypanosomal activity, Ethnomedicinal plants, Nupeland, Sleeping sickness, Trypanosomiasis, Trypanostatic effect

\section{Introduction}

Nigeria's biodiversity is rich in medicinal plants. Over $25 \%$ of our common medicines contain at least some compounds obtained from plants (Farnsworth, 1988). The World Health Organization reported that $70-90 \%$ of the worlds population relies chiefly on traditional medicine (WHO, 2004) and a major part of the traditional therapies involve the use of plant extracts or their active constituents. The local use of natural plants as primary health remedies is due to their pharmacological properties. Many plant extracts owe their potency to the presence of metabolites. These metabolites are usually found in various parts of the plants like roots, leaves, shoots and bark. Many plants have therefore become sources of important drugs and as such the pharmaceutical industries have exploited traditional medicine as a source of bioactive agents that can be used in the preparation of synthetic medicine (Kinghorn, 1994). Natural products play important roles in drug discovery and development process, particularly in the field of infectious diseases, where $75 \%$ of these drugs are of natural origin (Newman et al., 2003).

Trypanosomiasis, a disease of major importance in human and animals has continued to threaten human health and economical development (WHO, 1995; Kuzoe, 1993). T. b. gambiense and T. b. rhodesiense as the etiological agents of trypanosomiasis affect millions of people in sub-Saharan Africa and are responsible for the death of about half a million patients per year (Barrett, 1999).

Chemotherapy is the most widely used means of controlling the trypanosomiasis. The few registered trypanocides are often associated with severe side effects (Guttering, 1985) and require lengthy parenteral administration, lack efficacy and are unaffordable for most of the patients (Legros et al., 2002). There is urgent need to source for new, cheap and safe alternative chemotherapy against trypanosomiasis from natural origin.

In African countries where sleeping sickness is endemic, plants have traditionally been used for generations and are still widely used to treat this ailment with possible therapeutic activities, which have not been proved scientifically. However, Nupeland located on the coastal basins of Rivers Niger and Kaduna in North Central Nigeria is greatly influenced by the savannah-forest vegetations of the area. Naturally, this type of vegetation harbours tsetsefly which are the vector of trypanosomes, thus making the area highly endemic to sleeping sickness. Nupeland inhabited predominantly by Nupe tribe are agrarian in nature and practice farming with traditional medicine. Nupe tribe is traditionally noted for centuries of using medicinal plants in curing human 
trypanosomal infections among the indigenous people of Nupeland (Mann et al., 2003). Natural products derived from plants offer novel possibilities to obtain new drugs that are active against trypanosomes (Hoet et al., 2004).

Some Nigerian medicinal plants have been evaluated for their in vitro trypanocidal activity (Adewunmi et al., 2001; Atawodi et al., 2003; Maikai et al., 2008; Ogbunugafor et al., 2007; Owolabi et al., 1990; Shuaibu et al., 2008; Wurochekke and Nok, 2004) and in vivo antitrypanosomal efficacies in mice (Abubakar et al., 2005; Asuzu and Chineme,1990 ; Asuzu and Ugwuja 1989; Ibrahim et al., 2008 ; Mann et al., 2009; Ogbadoyi et al., 2007). The discovery of these potent antitrypanosomal extracts from plant has increased the great potentials of plant species to provide lead compounds for the development of new natural drugs for effective treatment of sleeping sickness. Therefore, the present study aimed to investigate the in vivo antitrypanosomal activity of Nupeland medicinal plants against $T$. b. brucei.

\section{Materials and Methods \\ Plant materials}

The plant materials (Z. zanthoxyloides (stem bark) T. avicennioides (round fruit) A. nilotica (stem bark) B. buonopozense (stem bark) with the following voucher Nos.: NIPRDH 68033, NIPRDH 5735, NIPRDH 02, NIPRDH 128 respectively were collected from a forest near Emitete village along Bida-Doko Road in Lavun local Government area of Niger State, Nigeria as described by the healers. They were botanically identified at the Herbarium Unit of the Department of Medicinal Plant Research and Traditional Medicine, National Institute for Pharmaceutical Research and Development, Garki - Abuja, Nigeria where voucher specimens were deposited.

\section{Preparation of plant extract}

The plant parts were air-dried to a constant weight. The dried parts were ground first into coarse form using a pestle and mortar and then reduced to a powdery form using a mill.

\section{Preparation of crude plant extracts}

The powdery plant materials $(250 \mathrm{~g})$ were separately soaked in $500 \mathrm{ml}$ of $70 \%$ methanol each for $24 \mathrm{hr}$ with constant stirring. The extracts were filtered through a clean muslin cloth $(2 \mathrm{~mm})$ and concentrated using a rotary evaporator. The concentrated extracts were dried under a ceiling fan at room temperature. The residue was weighed and used in the preparation of the stock extract for administration.

\section{Phytochemical screening of extracts}

Phytochemical screening of the plant extracts were carried out to assess the concentration of Alkaloids (Dragendorff's, Mayer's, and Wagner's reagents), Anthraquinones (Borntrager's test), Balsams (Ferric chloride solution test), Carbohydrate (Fehling's solution test), Cardiac glycosides (Salkowski's test and Keller-Kiliani's test), Flavonoids (Lead acetate test, Ferric chloride test, Shinoda's test), Resins (Acetic anhydride test + conc. $\mathrm{HS}_{2} \mathrm{O}_{4}$ ), Saponins (Froth test and Legal test), Tannins (Ferric chloride solution test, Bromine water test and Formaldehyde test), Terpenes (Liebermann-Burchard's test) in each plant sample using standard methods (Harborne, 1989; Sofowora, 1993; Trease and Evans, 1989).

\section{Trypanosome stock}

A stabilate of pleomorphic trypanosome bruce, strain (Trypanosoma brucei brucei) was obtained from the Nigerian Institute for Trypanosomiasis Research Vom, near Jos, Nigeria and maintained in the Laboratory of Department of Biochemistry by serial passage in mice.

\section{Experimental animals}

Mice used were purchased from the University of Ibadan and Ilorin and kept in well ventilated plastic cages. They were exposed to $12 \mathrm{hr}$ light and dark cycles and allowed free access to growers feed and water. The experiment was conducted in compliance with international accepted principles for laboratory animal use. Animal care guidelines on animal use protocol review (CCAC, 1997). The animals were allowed a 7-day period of acclimatization before they were divided into four groups of four animals per cage.

\section{Inoculation of donor mice}

Blood was collected by cardiac puncture with an EDTA coated syringe from a heavily infected mouse and immediately diluted with physiological saline. The dilute infected blood contains 1 or 2 parasite per field (microscopic field) $0.1 \mathrm{ml}$ of this blood was inoculated into two clean healthy mice intraperitoneally to serve as the donor. Infection was monitored every morning by microscopic examination of blood samples taken from the tail of the two infected mice. 


\section{Infection of animals}

Blood was collected by cardiac puncture with an EDTA coated syringe from the heavily infected mouse and immediately diluted with physiological saline to serve as the inoculum. Healthy mice were infected intraperitoneally with $0.01 \mathrm{ml}$ of the inoculums containing about 103 trypanosome cells. The extracts were administered every morning and parasitaemia was monitored every two days by microscope examination.

\section{Extract administration}

In order to determine the effective dose, seven groups of three mice each were distributed into cages. Four groups (I-IV) of mice were intraperitoneally administered extract at doses of $100,200,300$ and $500 \mathrm{mg} / \mathrm{kg}$ body weight per day. Group V was administered with Diminazene aceturate, Berenil (standard drug) at $3.5 \mathrm{mg} / \mathrm{kg}$ body weight per day. Group VI consist of the negative control which were infected with the parasite but were not treated with the extract. Group VII which were made up of Positive control were neither infected nor treated with the extract. Treatment was daily for 5 consecutive days. Parasitaemia was monitored every two days under the microscope.

\section{Therapeutic monitoring of extract}

Development of parasitaemia in these rats was checked daily by wet blood film prepared from tail blood at $\mathrm{x} 40$ magnification. The number of parasite seen per field under the microscope was counted as described by Herbert and Lumsden (1976).

\section{Results}

The plant extracts were percolated under laboratory conditions, and concentrated in vacuo with a rotary evaporator. Saponins, tannins and terpenes have been identified in all plant parts tested in all the four species. Alkaloids were found in only $B$. buonopozense. Flavonoids were also found in the extracts of A. nilotica (stem bark), T. avicennioides (round fruit) and $Z$. zanthoxyloides (stem bark) (Table 1).

Table 1: Phytochemical analysis of six crude plant extracts

Table 1: Phytochemical analysis of six crude plant extracts
\begin{tabular}{|l|l|l|l|l|}
\hline Test & A. nilotica & B. buonopozense & T. avicennioides & Z. zanthoxyloides \\
\hline Alkaloids & - & + & + & - \\
Tannins & + & + & + & + \\
Glycosides & + & - & + & + \\
Saponins & + & + & + & + \\
Terpenes & + & + & + & + \\
Sterols & + & - & - & - \\
Resins & - & + & + & + \\
Carbohydrates & + & - & - & - \\
Balsam & - & + & + & + \\
Flavonoids & + & - & - & - \\
Anthraquinones & + & - & + \\
\hline
\end{tabular}

Key $+=$ present, $-=$ absent

\section{Antitrypanosomal activity of crude plant extracts and their acute toxicity}

The acute toxicity of the extracts were determined and the appropriate dosage used for the trypanocidal efficacy. Those groups that were administered doses of $500 \mathrm{mg} / \mathrm{kg}$ body weight served as controls to check death resulting from the acute toxicity. For instance, the group administered with Z. zanthoxyloides at doses of $500 \mathrm{mg} / \mathrm{kg}$ body weight died on the fifth day of treatment. This shows that the extract was acutely toxic, because of the toxicity; the only dose that could suppress the activity of the parasite was $100 \mathrm{mg} / \mathrm{kg}$ body weight because they stayed six days after the death of the control. Those treated with $200 \mathrm{mg} / \mathrm{kg}$ body weight stayed four days after the death of the control as shown in table 2. The group treated with the standard drug, Diminazene aceturate 
(Berenil) survived. The drug was able to clear the parasite from circulation within three days of treatment. The effects of medicinal plant extracts on parasite count in mice infected with $T$. b. brucei are as shown in Tables II-V.

Table 2: Effect of A. nilotica on parasite count in mice infected with T. $b$. brucei

\begin{tabular}{|l|l|l|l|l|l|l|l|}
\hline Post treatment days & Group I & Group II & Group III & Group IV & Group V & Group VI & Group VII \\
\hline 2 & 0 & 0 & 0 & 0 & 0 & 0 & 0 \\
\hline 4 & 8 & 5 & 0 & D & D & 0 & 5 \\
\hline 6 & 100 & 0 & D & & & 0 & 100 \\
\hline 8 & 50 & 0 & & & & 0 & 150 \\
\hline 10 & 50 & 0 & & & & D & 200 \\
\hline 12 & 40 & 0 & & & & & D \\
\hline 14 & 20 & 0 & & & & & \\
\hline
\end{tabular}

\section{Key:}

$\mathrm{D}=$ Death of mice

Group I - Infected but treated with 100mg/kg of the extract; Group II - Infected but treated with $200 \mathrm{mg} / \mathrm{kg}$ of the extract; Group III - Infected but treated with $300 \mathrm{mg} / \mathrm{kg}$ of the extract; Group IV - Infected but treated with $500 \mathrm{mg} / \mathrm{kg}$ of the extract; Group V - Not infected but treated with $500 \mathrm{mg} / \mathrm{kg}$ of the extract; Group VI - Infected but treated with $3.5 \mathrm{mg} / \mathrm{kg}$ of Berenil; Group VII - Infected but not treated.

Table 3: Effect of B. buonopozense on parasite count in mice infected with T. $b$. brucei

\begin{tabular}{|l|l|l|l|l|l|l|l|}
\hline Post treatment days & Group I & Group II & Group III & Group IV & Group V & Group VI & Group VII \\
\hline 2 & 10 & 5 & 0 & 5 & 0 & 0 & 20 \\
\hline 4 & 30 & 25 & 10 & 10 & 0 & 5 & 50 \\
\hline 6 & 50 & 15 & 5 & 10 & 0 & 10 & 100 \\
\hline 8 & D & 10 & 3 & 5 & 0 & 0 & D \\
\hline 10 & & D & 0 & D & 0 & 0 & \\
\hline 12 & & & 0 & & 0 & 0 & \\
\hline 14 & & & 0 & & 0 & 0 & \\
\hline
\end{tabular}

\section{Key:}

$\mathrm{D}=$ Death of mice

Group I - Infected but treated with 100mg/kg of the extract; Group II - Infected but treated with 200mg/kg of the extract; Group III - Infected but treated with $300 \mathrm{mg} / \mathrm{kg}$ of the extract; Group IV - Infected but treated with $500 \mathrm{mg} / \mathrm{kg}$ of the extract; Group V - Not infected but treated with $500 \mathrm{mg} / \mathrm{kg}$ of the extract; Group VI - Infected but treated with $3.5 \mathrm{mg} / \mathrm{kg}$ of Berenil; Group VII - Infected but not treated.

Table 4: Effect of T. avicennioides on parasite count in mice infected with T. b. brucei

\begin{tabular}{|l|l|l|l|l|l|l|l|}
\hline Post treatment days & Group I & Group II & Group III & Group IV & Group V & Group VI & Group VII \\
\hline 2 & 0 & 0 & 0 & 0 & 0 & 0 & 0 \\
\hline 4 & 0 & 0 & 10 & 25 & 0 & 0 & 10 \\
\hline 6 & 10 & 50 & 60 & 60 & 0 & 5 & 150 \\
\hline 8 & 50 & D & 100 & 90 & 0 & 0 & D \\
\hline 10 & 100 & & 100 & 90 & 0 & 0 & \\
\hline 12 & D & & 150 & D & 0 & 0 & \\
\hline 14 & & & D & & D & 0 & \\
\hline
\end{tabular}

Key:

$\mathrm{D}=$ Death of mice

Group I - Infected but treated with $100 \mathrm{mg} / \mathrm{kg}$ of the extract; Group II - Infected but treated with $200 \mathrm{mg} / \mathrm{kg}$ of the extract; Group III - Infected but treated with $300 \mathrm{mg} / \mathrm{kg}$ of the extract; Group IV - Infected but treated with $500 \mathrm{mg} / \mathrm{kg}$ of the extract; Group V - Not infected but treated with $500 \mathrm{mg} / \mathrm{kg}$ of the extract; Group VI - Infected but treated with $3.5 \mathrm{mg} / \mathrm{kg}$ of Berenil; Group VII - Infected but not treated.

\section{Discussion}

Investigation of antitrypanosomal activity of traditionally used plants has been a major area of contemporary research focus. Natural products such as alkaloids, terpenes, quinones, and polyphenols found in these extracts have been shown to be potent growth inhibition of T. cruzi (Wright and Pillipson, 1990). Triterpenoids and sterols from the plants are reported to possess antitrypanosomal activity (Hoet et al., 2007). The antitrypanosomal activities of alkaloids like actinodaphine, dicentine, cassythine isolated from Cassytha filiformis (Hoet et al., 2004a) are also found in B. buonopozense and several other alkaloids (Merschjohann et al., 2001) displayed significant in vitro antitrypanosomal activity. The DNA intercalation in combination with portion 
biosynthesis inhibition is reported to be the mechanism of action responsible for the observed anti-trypanosomal effect of the active alkaloids (Merschjohann et al., 2001). The trypanocidal activity of several flavonoids such as quercetagetin (Hoet et al., 2004b); hispidulin and santin (Sülsen et al., 2007) has been previously reported. An azaanthraquinone early reported in A. nilotica was associated with the observed antitrypanosomal effects (Nok, 2002).

Table 5: Effect of $Z$. zanthoxyloides on parasite count in mice infected with T. $b$. brucei

\begin{tabular}{|l|l|l|l|l|l|l|l|}
\hline Post treatment days & Group I & Group II & Group III & Group IV & Group V & Group VI & Group VII \\
\hline 2 & 0 & 0 & 0 & 0 & 0 & 0 & 0 \\
\hline 4 & 0 & 0 & 0 & 0 & 0 & 0 & 80 \\
\hline 6 & 0 & 0 & 0 & D & D & 8 & 90 \\
\hline 8 & 80 & 80 & 65 & & & 0 & 100 \\
\hline 10 & 100 & 100 & 100 & & & 0 & D \\
\hline 12 & 100 & 110 & 100 & & & 0 & \\
\hline 14 & 120 & D & D & & & 0 & \\
\hline
\end{tabular}

Key:

$\mathrm{D}=$ Death of mice

Group I - Infected but treated with 100mg/kg of the extract; Group II - Infected but treated with $200 \mathrm{mg} / \mathrm{kg}$ of the extract; Group III - Infected but treated with $300 \mathrm{mg} / \mathrm{kg}$ of the extract; Group IV - Infected but treated with $500 \mathrm{mg} / \mathrm{kg}$ of the extract; Group V - Not infected but treated with $500 \mathrm{mg} / \mathrm{kg}$ of the extract; Group VI - Infected but treated with $3.5 \mathrm{mg} / \mathrm{kg}$ of Berenil; Group VII - Infected but not treated.

\section{Antitrypanosomal activity of crude plant extracts tested in vivo}

The crude extract of the stem bark of Z. zanthoxyloides shows no trypanocidal activity. However, it was found to be trypanostatic since parasite were undetected between day one of infection and day five of treatment. The present result showed that $100 \mathrm{mg} / \mathrm{kg}$ of the doses administered is trypanostatic because the parasitaemia was kept relatively low when compared to the untreated. The group infected but not treated died between the $7^{\text {th }}$ day and $8^{\text {th }}$ day of infection while those infected and treated died days after.

In our present studies, we focused on in vivo screening of Z. zanthoxyloides (stem bark) T. avicennioides (round fruit), A. nilotica (stem bark) and B. buonopozense (stem bark) which are the plant parts prominently used in Nupe Ethnomedicine (Mann et al., 2003). Therefore, the antitrypanosomal activity of four crude methanol extracts of medicinal plants from Nupeland was determined in vivo using T. b. brucei as shown in Tables II-IV. The crude extract of the stem bark of Z. zanthoxyloides had no trypanocidal effect, even though its root bark extract was reported to be active (Igweh and Onabanjo, 1989). The failure of the crude extract of the stem bark of $Z$. zanthoxyloides to show any trypanocidal action depicts that the anti-trypanosomes are lacking in the stem bark as opposed to the claims by the healers which according to the existing literature is used in Nupe ethnomedicine in the management of sleeping sickness in Nupeland (Mann et al., 2003)However, we have also observed that the crude extract of the stem bark of $Z$. zanthoxyloides was found to exhibit trypanostatic activity. Similar to the early reports of the trypanostatic effect of ethanolic extract of the stem bark of $F$. albida and it is also effective in the management of anaemia induced by $T$. b. brucei in rats (Tijani et al., 2009). Trypanostatic effect is said to suppress the activity of the parasite there by sustaining the life of the mice when compared to the control group. It is worthy to mention that some plants have already been investigated for their antitrypanosomal activity in other studies. For instance; water, methanol and dichloromethane extracts of the leaves of T. avicennioides tested, but only methanolic extracts were active on $T$. b. brucei (Bizimana et al., 2006). Stem bark extracts of the same plant species has shown in vitro effect against T. b. brucei (Shuaibu et al., 2008).

In our present studies, the round fruit extract of $T$. avicennioides tested for its in vivo antitrypanosomal activity gave a result that are efficaciously comparable to those of previous investigators who showed that extracts of $T$. avicennioides were active in vitro on T. b. brucei (Bizimana et al., 2006; Shuaibu et al., 2008). T. avicennioides (round fruit) and Z. zanthoxyloides (stem bark) were effective on trypanosomes trypanostatically only.

The most interesting results are those of A. nilotica and B. buonopozense extracts which showed the antitrypanosomal effects at 200 and $300 \mathrm{mg} / \mathrm{kg}$ body weight respectively representing the first time in vivo activity of B. buonopozense and $Z$. zanthoxyloides on trypanosome, T. b. brucei is being reported. Doses were able to clear the parasites from circulation within 6 and 7 days of treatment respectively with prolonging survival period of up to 30 days. While the extracts of T. avicennioides and $Z$. zanthoxyloides showed trypanostatic effects and could not clear the parasites completely.

From the phytochemical studies, the type of compounds which could be responsible for the antitrypanosomal activities are associated with the metabolites and the results obtained showed that the crude extract of Z. zanthoxyloides contain some metabolites that suppresses the activity of the trypanosomes rather than killing the parasites completely.

This study has provided evidence that $T$. avicennioides and Z. zanthoxyloides extracts exhibits trypanostatic effect which is often associated with reduction in anemia and promote weight gain in experimental African trypanosomiasis (Ogbadoyi et al., 1999). Anaemia is the most outstanding clinical and laboratory feature of African trypanosomiasis (Bizimana et al., 2006) and also the primary cause of death (Mamo and Holmes, 1975). The stem bark of Z. zanthoxyloides is used in treating sickle cell anaemia and analgesic (Mann et al., 2003). Trypanostatic effect of the plant extracts were explained with corresponding increase in PCV 
which prolong the lifespan of treated animals by reducing the parasite load or neutralizing the toxic metabolites produced by trypanosomes (Abubakar et al., 2005). Based on these results and the fact that plant part extracts are traditionally used in the treatment of African Trypanosomiasis, we analyzed in greater detail the antitrypanosomal activity of the stem bark methanol extracts of the four plants. Nevertheless, the activity values for the active extracts were high compared to the values obtained for commonly used trypanocidal drugs diminazene aceturate. However, since the crude extracts have a very complex composition, purification might lead to pure compounds with highly increased activity. Such differences between our results and those of other authors may be due to the known variation in the chemical composition of plants according to the geographical area and the time or season of collection (Shuaibu et al., 2008).

In our in vivo studies, with mice infected with T. b. brucei; the methanol extracts of round fruit of T. avicennioides and stem barks of Z. zanthoxyloides and A. nilotica and B. buonopozense were investigated, but only A. nilotica and B. buonopozense were found to be significantly active. The antitrypanosomal activity of four crude methanol extracts of medicinal plants from Nupeland determined by in vivo using T. b. brucei, only A. nilotica and B. buonopozense were the most promising ones. This is the first report of in vivo antitrypanosomal activity of these two plants. The results of the present study confirmed that the use of medicinal plants in folk medicine contributes significantly to primary health care, and that natural products are potential sources of new drugs for the treatment of important tropical diseases caused by trypanosomes. The high activity values obtained for these plants render them candidates for the isolation of anti-trypanosomal compounds which could be developed into new lead structures for drug development. Therefore, the trypanocidal effects of extracts will require further experimentation after fractionation and characterization using chromatographic and spectroscopic techniques, a work that is currently in progress.

\section{Acknowledgement}

Our greatest appreciation goes to all Herbal healers consulted, especially Baba Alhassan Bangbara Bida who supplies the ethnobotanical information of these plants. We also thank the management of Department of Biochemistry, Federal University of Technology Minna, P. M. B. 65, Minna, Niger State, Nigeria for using their laboratory facilities. We are also grateful to Mal Muazzim Ibrahim of the Herbarium Unit of the Department of Medicinal Plant Research and Traditional Medicine, National Institute for Pharmaceutical Research and Development, Garki - Abuja, Nigeria for identifying the plant species.

\section{References}

1. Abubakar A, Iliyasu B, Yusuf AB, Onyekwelu NA, Igweh AC, Shamaki BU, Afolayan, DO and Ogbadoyi EO (2005). Antitrypanosomal and hematological effects of selected Nigerian medicinal plants in Wistar rats. Biokemistri 17: 95-99.

2. Adewunmi CO, Agbedahunsi JM, Adebajo AC, Aladesanmi AJ, Murphy N and Wando J (2001). Ethno-veterinary medicine: screening of Nigerian medicinal plants for trypanocidal properties. J Ethnopharmacol. 77: 19-24.

3. Asuzu IU and Chineme CN (1990). Effects of Morinda lucida leaf extracts on Trypanosoma brucei brucei infection in mice. J Ethnopharmacol. 30: 307-313.

4. Asuzu IU and Ugwuja MO (1989). A preliminary study of the biological activities of the bark extract of Piliostigma thonningii (Schum) in mice. Phytother Res. 35: 209-211.

5. Atawodi SE, Bulus T, Ibrahim S, Ameh DA, Nok AJ, Mamman M and Galadima M (2003). In vitro trypanocidal effect of methanolic extract of some Nigerian savannah plants. Afri J Biotech. 2(9):317-321.

6. Barrett MP (1999). The fall and rise of sleeping sickness. The Lancet 353: 1113-1114.

7. Bizimana N, Tietjen U, Zessin K-H, Diallo D, Djibril C, Melzig MF and Clausen P-H (2006). Evaluation of medicinal plants from Mali for their in vitro and in vivo trypanocidal activity. J Ethnopharmacol. 103(3): 350-356.

8. CCAC (1997). Guidelines on: Animals use and protocol Review.

9. Farnsworth NR (1988). Screening plants for new medicines. In: Biodiversity (Ed) by Wilson EO. Washington DC: National Academy Press, pp 83-97.

10. Guttering WE (1985). Existing chemotherapy and its limitations. Br Med Bull. 41: 162-168.

11. Harborne JB (1989). Phytochemical Methods: A Guide to Modern Techniques of Plant Analysis. London: Chapman and Hall Ltd, pp 7-8.

12. Herbert WJ and Lumsden WHR (1976). Trypanosome brucei. A rapid matching method for estimating the hosts Parasitaemia. Exp Parasitol. 40: 423-431.

13. Hoet S, Opperdoes FR, Brun R, Adjakidjé V and Quetin-Leclercq J (2004a). In vitro antitrypanosomal activity of ethnopharmacologically selected Beninese plants. J Ethnopharmacol. 91: 37-42.

14. Hoet S, Opperdoes FR, Brun R and Quetin-Leclercq J (2004). Natural products active against African trypanosomes: a step towards new drugs. Nat Prod Rep. 21(3):353-364.

15. Hoet S, Pieters L, Muccioli GG, Habib-Jiwan J-L, Opperdoes FR and Quetin-Leclercq J (2007). Antitrypanosomal Activity of Triterpenoids and Sterols from the Leaves of Strychnos spinosa and Related Compounds. J Nat Prod. 70(8):1360 -1363.

16. Hoet S, Stervigny C, Block S, Opperdoes FR, Colson, P, Baldeyrou B, Lansiaux A, Bailly C and Quetin-Leclercq J (2004b). Alkaloids from Cassytha filiformis and related Aporphines: Antitrypanosomal activity, cytotoxicity, and Interaction with DNA and Topoisomerases. Planta Med. 70: 407-413. 
17. Ibrahim MA, Njoku GC and Sallau AB (2008). In vivo activity of stem bark aqueous extract of Khaya senegalensis against Trypanosoma brucei. Afri J Biotech. 7 (5): 661-663.

18. Igweh AC and Onabanjo AO (1989). Chemotherapautic effects of Annona senegalensis in Trypanosoma brucei brucei. Ann Trop Med Parasitol. 83: 527-534.

19. Kinghorn AD (1994). The discovery of drugs from higher plants. Biotechnol. 26: 81- 108.

20. Kuzoe FAS (1993). Current situation of African trypanomiasis. Acta Tropica 54:153-162.

21. Legros D, Ollivier G, Gastellu-Etchegorry M, Paquet C, Burri C, Jannin J and Buscher P (2002). Treatment of human African trypanosomiasis - present situation and needs for research and development. The Lancet, Infectious Diseases 2:437-440.

22. Maikai VA, Nok JA, Adaudi AO and Alawa CB (2008). In vitro antitrypanosomal activity of aqueous and methanolic crude extracts of stem bark of Ximenia americana on Trypanosoma congolense. J Med Plants Res. 2(3): 055-058.

23. Mamo E and Holmes P (1975). The erythrokinetics of zebu cattle chronically infected with T. congolense. Research in Veterinary Sci. 18: 105-106.

24. Mann A, Egwim EC, Banji B, Umar AN, Gbate M and Ekanem JT: (2009). Efficacy of Dissotis rotundifolia on Trypanosoma brucei brucei infection in rats Afri J Biochem Res. 3(1): 005-008.

25. Mann A, Gbate M, Nda-Umar A (2003). Medicinal and Economic Plants of Nupeland. Bida, Niger State, Nigeria: Jube-Evans Books and Publications, pp 276.

26. Merschjohann K, Sporer F, Steverding D and Wink M (2001). In vitro Effect of Alkaloids on Bloodstream forms of Trypanosoma brucei and T. congolense. Planta Med. 67: 623-627.

27. Newman D, Cragg G and Snader K (2003). Natural products as sources of new drugs over the period 1981-2002. J Nat Prod. 66: $1022-1037$.

28. Nok AJ (2002). Azaanthraquinone inhibits respiration and in vitro growth of long slender bloodstream forms of T. congolense. Cell Biochemistry and Function 20: 205-212.

29. Ogbadoyi EO, Akinsunbo AO, Adama TZ and Okogun JI (2007). In vivo Trypanocidal activity of Annona senegalensis leaf extract against Trypanosoma brucei brucei. J Ethnopharmacol. 112: 85-89.

30. Ogbadoyi EO, Ukoha AI and Keywalabe, E (1999). Anemia in experimental African Trypanosomiasis. The J. Protozool. Res. 9(2): 55-63.

31. Ogbunugafor HA, Okochi VI, Okpuzor J, Adedayo T and Esue S (2007). Mitragyna ciliata and its trypanocidal activity. Afri J Biotech. 6(20): 2310-2313.

32. Owolabi OA, Makanga B, Thomas EW, Molyneux DH and Oliver RW (1990). Trypanocidal potentials of Africa woody plants. In vitro trials of Khaya grandifoliolium seed extracts. J Ethnopharmacol. 30: 227-231.

33. Shuaibu MN, Wuyep PTA, Yanagi T, Hirayama K, Ichinose A, Tanaka T and Kouno I (2008). Trypanocidal activity of extracts and compounds from the stem bark of Anogeissus leiocarpus and Terminalia avicennioides. Parasitol Res. 102 (4): 697-703.

34. Sofowora A (1993). Medicinal Plants and Traditional Medicine in Africa. Ibadan: Spectrum Books.

35. Sülsen VP, Cazorla SI, Frank FM, Redko FC, Anesini, CA, Coussio JD, Malchiodi, EL, Martino VS and Muschietti LV (2007). Trypanocidal and Leishmanicidal Activities of Flavonoids from Argentine Medicinal Plants. Am. J. Trop. Med. Hyg. 77(4): 654-659.

36. Tijani AY, Uguru MO, Salawu OA, Abubakar A, Onyekwelu NO and Akingbasote JA (2009). Effect of Faidherbia albida on some biochemical parameters of rats infected with Trypanosoma brucei bruce. Afri J Pharm Pharmacol. 3(1): 026-030.

37. Trease GE and Evans WC (1989). Pharmacognosy13th Edition. London: Bailliere Tindall.

39. WHO (1995). World Health Reports. Bridging the gap, WHO, Geneva, 1:118.

40. WHO (2004). Medicinal plants - guidelines to promote patient safety and plant conservation for a US\$ 60 billion industry, http://www.who.int/mediacentre/notes/2004/np3/en.

41. Wright CW and Phillipson JD (1990). Natural products and the development of selective antiprotozoal drugs. Phytother. Res. 4:127-139.

42. Wurochekke AU and Nok AJ (2004). In vitro anti trypanosomal activity of some medicinal plants used in the treatment of trypanosomiasis in Northern Nigeria. Afri J Biotech. 3(9): 481-483. 